\title{
Laryngeal lipoma: a rare cause of acute intermittent airway obstruction
}

\author{
Peter George Deutsch, Janet O'Connell
}

Department of Otolaryngology, Sandwell and West Birmingham Hospitals NHS Trust, Birmingham, UK

\section{Correspondence to} Peter George Deutsch, peter.deutsch@nhs.net

Accepted 10 April 2016

\section{CrossMark}

To cite: Deutsch PG O'Connell J. BMJ Case Rep Published online: [please include Day Month Year] doi:10.1136/bcr-2016215506

\section{SUMMARY}

We present a case of a 62-year-old man with a lipoma in the exceedingly rare location of the larynx, causing intermittent airway obstruction and dysphagia. The lipoma was excised endoscopically with complete resolution of symptoms. Lipomas are relatively common, accounting for $4-5 \%$ of all benign tumours in the body. They traditionally occur in areas of large depositions of subcutaneous fat, most frequently the trunk and limbs. They are recognised to occur in the head and neck but these only represent $13-15 \%$ of all lipomas. Lipomas are typically asymptomatic unless their impingement of nearby structures causes symptoms.

\section{BACKGROUND}

Acute airway obstruction is an immediately lifethreatening emergency. There are a range of pathologies that can cause airway obstruction including, but not limited to, infective processes, vascular anomalies, external compression, foreign bodies and benign or malignant tumours. Intermittent airway obstruction is a less commonly seen entity but still requires prompt diagnosis and management. Owing to its infrequent presentation it is often missed, with symptoms being attributed to other causes.

Lipomas of the larynx are rare with only around 100 being reported in the literature. ${ }^{1-3}$ However, due to their location and their frequently pedunculated nature, they have been recognised to cause intermittent obstruction of the airway. ${ }^{2-5}$ There have been different approaches to management discussed in the literature, including endoscopic, transoral robot assisted and open excision. ${ }^{2}$ 5-7

This case provides the classical history of a patient presenting with a prolapsing laryngeal lesion who was managed simply with endoscopic excision and made a complete recovery. This case also highlights the wide range of differential diagnoses a presentation such as this can give rise to, especially given the significant smoking history. We hope this case will raise awareness of intermittent airway obstruction and laryngeal lipomas as a cause of this.

\section{CASE PRESENTATION}

A 62-year-old Caucasian man was referred to the head and neck outpatients clinic after having a lesion in his larynx noted on a CT scan of his neck and thorax. He had a medical history of a right radical nephrectomy for clear cell carcinoma, transitional cell carcinoma of the bladder, a previously excised chondroid syringioma of the face (a rare benign mixed tumour arising from sweat glands), unstable angina and hypercholesterolaemia. ${ }^{8}$ His medication history included only aspirin and a statin. He was a heavy smoker with a 63-pack-year history, occasionally drank alcohol and worked as an electric motor fitter. He had a strong family history of cardiovascular disease.

The patient initially presented to the cardiology department as an emergency admission. He reported sitting up in bed on the morning of admission and feeling as if 'a trap door snapped shut' on his airway. During the episode he felt some chest tightness and sweating but no chest pain. He managed to call an ambulance but reported significant dysphonia. On arrival, as he lay in the ambulance, he felt as if 'a plug had been pulled out' and he could breathe normally again. The paramedics could not find any abnormalities in the patient's observations nor on examination, and agreed with the patient not to take him to accident and emergency but to have him followed up by his general practitioner. The patient attended his surgery later that day and the doctor reviewing the ECG trace from the ambulance arranged for urgent review by the on call cardiologist for a suspected myocardial infarction.

On admission to the hospital, the patient was found to have a borderline rise in cardiac enzymes and so underwent coronary angiography. This revealed mild diffuse disease to the left anterior descending and left circumflex coronary artery, and mild to moderate disease of the right coronary artery. There was, however, no evidence of acute myocardial infarction. He was therefore managed medically with aspirin and atorvastatin.

During his admission under the cardiology team, he was noted to have clubbing of his fingers and a diffuse non-tender goitre. On further questioning, he reported some swallowing difficulties, namely occasional need for 'double-swallow' of solids and an intermittent 'lump in the throat' sensation. He reported no loss of weight, and neither lethargy nor change in voice. Thyroid function tests were normal. As a result of these clinical findings and history, a CT of the neck and thorax was organised for suspected pulmonary and head neck malignancy, or a compressive thyroid goitre. As well as this, an ultrasound of his thyroid was requested. The CT showed a lesion in the left laryngopharynx, suggestive of a laryngeal lipoma (figure 1).

It was at this stage that the patient was highlighted to the head and neck team and seen in the outpatient clinic. The history on this occasion was unchanged, with a normal voice and some mild 


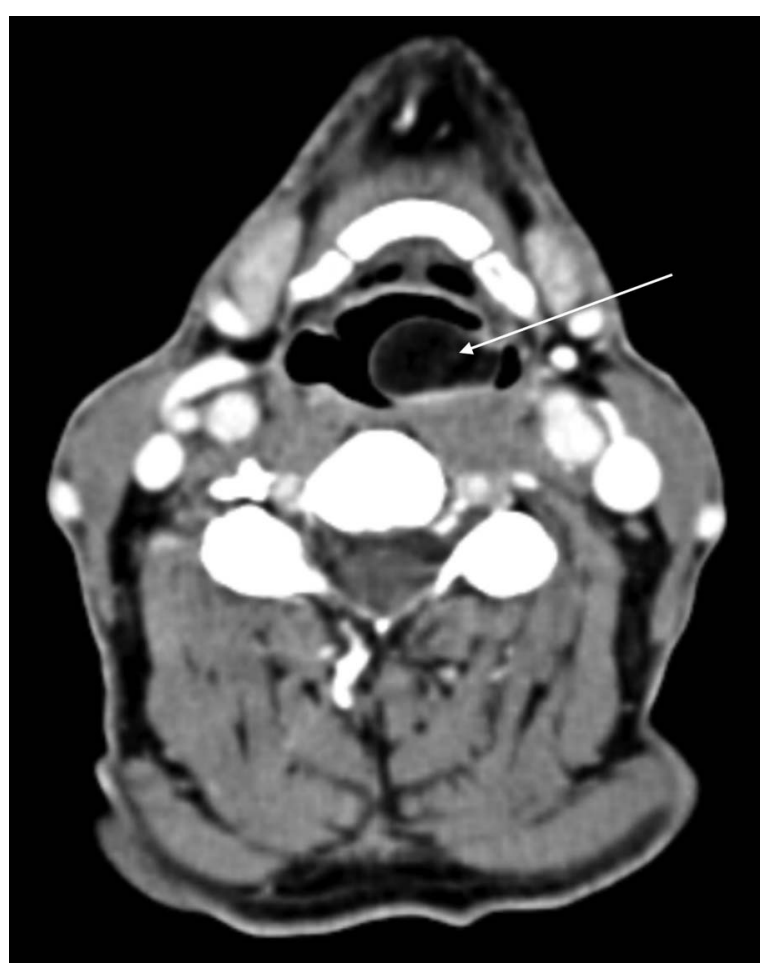

Figure 1 Axial slice at the level of the larynx, showing a large, well-defined low attenuating lipoma in the left laryngopharynx.

dysphagia. Flexible nasendoscopy showed a large polypoidal lesion arising from the left aryepiglottic fold and prolapsing into the larynx, partially obstructing the airway. The rest of the larynx and vocal cords were unremarkable. The patient was therefore listed for a microlaryngoscopy to assess the lesion further and remove it if possible. He was also consented for a tracheostomy in case there were any issues with his airway.

\section{INVESTIGATIONS}

The CT scan showed no significant compression from the thyroid goitre, however, it did reveal a well-defined spherical low attenuating lesion in the left posterior laryngopharynx (figure 1). This was radiologically suggestive of a lipoma in the larynx. There was no evidence of malignancy.

The ultrasound showed a diffuse goitre with multiple small cysts, one of which was indeterminate in nature radiologically, so a fine-needle aspiration cytology (FNAC) sample was sent. Thyroid function tests were unremarkable. The FNAC of the thyroid nodule was inconclusive and a repeat ultrasound failed to identify any suspicious nodules, therefore another sample was not taken.

\section{DIFFERENTIAL DIAGNOSIS}

The diagnosis in the first instance was rather elusive and, as such, the differential diagnosis was somewhat broader until the CT scan and coronary angiogram were performed, when it became more refined.

- Acute coronary syndrome

- Respiratory tract infection

- Pulmonary malignancy

- Laryngeal malignancy

- Compressive thyroid goitre

- Laryngeal polyp

- Laryngeal lipoma/liposarcoma

\section{TREATMENT}

The patient was admitted as an elective case for a microlaryngoscopy, where a large left laryngeal polyp measuring $30 \times 25 \times 20 \mathrm{~mm}$ was found. This had a relatively broad base posterior to the left arytenoid. The lesion was excised along its pedicle en mass and sent for histology. The patient was observed overnight and discharged the following day.

Histology revealed a $6.2 \mathrm{~g}$ uniform, fleshy yellow lesion covered by a slightly keratinised stratified squamous mucosa. The lesion itself was a simple lipoma made up mature adipocytes. It was completely excised.

\section{OUTCOME AND FOLLOW-UP}

The patient was discharged the day after excision of the lipoma. He was symptom-free on discharge. He was followed up in the clinic after 2 months and again at 6 months, and reported complete resolution of his dysphagia and no further episodes of airway obstruction. He did, however, reveal that he had had a few further occasions of airway obstruction prior to being seen in the ear, nose and throat clinic on the first occasion, which were immediately relieved by lying flat. He had chosen not to disclose these in the clinic setting for fear of being readmitted to hospital. His goitre persists but shows no worrying features.

\section{DISCUSSION}

Lipomas are slow growing, well circumscribed benign tumours of mesenchymal origin. ${ }^{9}$ They are generally asymptomatic unless they cause impingement or compression of surrounding structures. ${ }^{1}$ They occur commonly on the trunk and limbs as these are areas of high subcutaneous fat content, and they account for $4-5 \%$ of all benign tumours in the human body. ${ }^{2}$ Lipomas are more commonly found in males (62.5\%) and have their peak incidence in the fourth and fifth decade of life, however, lipomas and indeed laryngeal lipomas have also been described in the paediatric population. ${ }^{2}{ }^{5}$ No definitive aetiology or risk factors have been identified. ${ }^{2}$ They are recognised to occur in the head and neck region, representing $13-15 \%$ of all lipomas. ${ }^{2}$ The most common site in the head and neck is the posterior triangle of the neck. ${ }^{5}$ Their occurrence in the larynx, however, is far less common, accounting for just $0.6 \%$ of all benign laryngeal lesions. ${ }^{3}$ In the literature, there are roughly 100 cases reported. $^{2}{ }^{3}$ The largest review found was carried out in 1965 by Zakrzewski. ${ }^{10}$ This subdivided laryngeal lipomas into two types: the author described extrinsic lipomas (posterior surface of arytenoid, lingual surface of epiglottis and pharyngeal wall) as being more common than true 'intrinsic' laryngeal lipomas $(77 \%$ vs $23 \%){ }^{3}{ }^{10}$ This is due to a relative lack of adipose tissue deposition in the larynx, with a small amount of adipose tissue found at the aryepiglottic fold, false cords and epiglottis. ${ }^{12}$ They occur much less frequently at sites of no adipose tissue deposition such as the true cords. ${ }^{3}$ The location of the lipoma can affect symptomatology and hence presentation. Owing to their slow growth, symptoms are usually absent or very insidious in the early stages. Commonly the symptom of sensation of a lump in the throat is present as well as dysphagia in larger lesions. ${ }^{3}$ If the lesion is of an intrinsic type it can impinge directly on vocal cord function leading to hoarseness. ${ }^{15}$ Our case represents an extrinsic pedunculated laryngeal lipoma causing symptoms of dysphagia, sensation of a lump in the throat and intermittent airway compromise.

Various different histological types of lipoma in the oral cavity and larynx have been described, including fibrolipoma and spindle cell lipoma, but malignant types have also been 
described, such as liposarcomas, with similar symptomatology. ${ }^{2} 6$ Any recurrence of lipoma after excision should raise concerns of a malignant subtype. ${ }^{3}$

Imaging is recommended in cases of intermittent airway obstruction and if a laryngeal lipoma is suspected clinically. Cross-sectional imaging is required with either a CT scan or MRI. ${ }^{11}$ There have been no randomised trials to compare the use of CT and MRI in evaluating laryngeal lipomas, but both have been suggested to aid diagnosis and plan management strategies. $^{2} 12$ CT scans are quicker and more readily available, and show lipomas as well circumscribed low attenuating lesions. ${ }^{2}$ However, MRI gives good soft tissue differentiation allowing for accurate evaluation of the lipoma margins, especially on sagittal reconstruction, and so has been suggested by some to be superior to $\mathrm{CT}^{13}$

Management of laryngeal lipomas is surgical with three methods described-endoscopic, transoral robot assisted and

\section{Patient's perspective}

The episodes of my throat closing off were very scary experiences initially, however, when I realised that it got better when I lay down, I didn't find them as worrying. I'm very glad that it was found and taken out without causing me too many problems.

\section{Learning points}

- Intermittent airway obstruction is an uncommon presenting symptom and is not widely appreciated, but could have drastic consequences if missed.

- Careful and detailed history-taking is of utmost importance in early identification of the location of pathology.

- Thyroid swelling is a recognised cause of airway compression and dysphagia, but it is uncommon and does not present with intermittent airway obstruction. Other causes should be sought simultaneously in this situation.

- Endoscopic and open approaches can be considered for laryngeal lipoma excision, depending on the location and morphology of the tumour. open via a transverse neck incision using a thyrotomy, lateral pharyngotomy or a transhyoid approach..$^{25-7}$ Reviewing the literature, successful endoscopic removal has been achieved in pedunculated tumours that are visible in their entirety on microlaryngoscopy, as in this case. ${ }^{14}$ However, non-pedunculated and submucosal lesions are more likely to require an external approach. $^{2}{ }^{3} 7$ Follow-up of all these patients has been recommended due to the risk of a late recurrence. ${ }^{25}$

Other causes of intermittent airway obstruction from benign lesions have been described, such as large granulomas and fibrovascular polyps causing a 'ball-valve' type of obstruction. ${ }^{13}{ }^{14}$ All these lesions should be examined further with excision or biopsy with the aid of imaging to rule out malignant causes.

Competing interests None declared.

Patient consent Obtained.

Provenance and peer review Not commissioned; externally peer reviewed.

\section{REFERENCES}

1 Demir D, Eraslan Ö, Güven $M$, et al. Rare cases of benign tumors of the head and neck: lipoma of larynx and sternocleidomastoid muscle. Kulak Burun Bogaz Ihtis Derg 2016:26:118-22.

2 De Vincentiis M, Greco A, Mascelli A, et al. Lipoma of the larynx: a case report. Acta Otorhinolaryngol Ital 2010;30:58-63.

3 Ashtiani MTK, Yazdani N, Saeedi M, et al. Large lipoma of the larynx: a case report. Acta Medica Iranica 2010;48:353-6.

4 Jungehülsing $M$, Fischbach $R$, Pototschnig C, et al. Rare benign tumors: laryngeal and hypopharyngeal lipomata. Ann Otol Rhinol Laryngol 2000;109:301-5

5 Abtahi SH, Eshaghian A, Abootalebian F. Lipoma of paraglottic space in a child: a case report. Iran J Otorhinolaryngol 2014;26:267-9.

6 Kodiyan J, Rudman JR, Rosow DE, et al. Lipoma and liposarcoma of the larynx: case reports and literature review. Am J Otolaryngol 2015;36:611-15.

7 Ueha R, Nito T, Sakamoto T, et al. Supra-thyroid alar cartilage approach for the complete resection of laryngeal submucosal tumors and postoperative voice quality. Eur Arch Otorhinolaryngol 2015;272:2907-13.

8 Girgis S, Gillan G, Piper K. Rare benign mixed tumour of the upper lip: a case report. Ann Med Surg (Lond) 2015;4:380-3.

9 Magadum D, Sanadi A, Agrawal JM, et al. Classic tongue lipoma: a common tumour at a rare site. BMJ Case Rep 2013;2013:bcr2012007987.

10 Zakrzewski A. Subglottic lipoma of the larynx. (Case report and literature review). J Laryngol Otol 1965;79:1039-48.

11 Dammann F, Bootz F, Cohnen $\mathrm{M}$, et al. Diagnostic imaging modalities in head and neck disease. Dtsch Arzteb/ Int 2014;111:417-23.

12 El-Monem MHA, Gaafar AH, Magdy EA. Lipomas of the head and neck: presentation variability and diagnostic work-up. J Laryngol Otol 2006; 120:47-55

13 Nascimento SB, Santos FC, Pinheiro Mde N. Giant fibrovascular polyp of the larynx. Int Arch Otorhinolaryngol 2014;18:325-7.

14 Lai S, Kelleher K, Sataloff RT. Vocal fold granuloma: the "ball-valve" phenomenon. Ear Nose Throat J 2000;79:836.

Copyright 2016 BMJ Publishing Group. All rights reserved. For permission to reuse any of this content visit http://group.bmi.com/group/rights-licensing/permissions.

BMJ Case Report Fellows may re-use this article for personal use and teaching without any further permission.

Become a Fellow of BMJ Case Reports today and you can:

- Submit as many cases as you like

- Enjoy fast sympathetic peer review and rapid publication of accepted articles

- Access all the published articles

- Re-use any of the published material for personal use and teaching without further permission

For information on Institutional Fellowships contact consortiasales@bmjgroup.com

Visit casereports.bmj.com for more articles like this and to become a Fellow 